\title{
PERAN DAN STRATEGI PENGEMBANGAN WISATA AIR TERJUN KEBO AMUK (TEDUNAN) DALAM MENINGKATKAN \\ EKONOMI MASYARAKAT DESA SITILUHUR KECAMATAN GEMBONG KABUPATEN PATI
}

\author{
Faiz Aminuddin \\ Dosen Institut Pesantren Mathali'ul Falah Pati \\ Email: fifa-iz@yahoo.com \\ Abdul Mutholib \\ Peneliti Wisata Air Terjun Kebo Amuk Sitiluhur \\ Email: abdulmutholib@gmail.com
}

\begin{abstract}
The role and tourism development strategy waterfall Kebo Amuk (Tedunan) in improving the economy villagers Sitilubur in Gembong Pati. Skripsi. Pati: the faculty dakwah and community development institute Mathali'ul Falah 2017. Indonesia country is a that has the potential resources abounding, biodiversity and that which remained history and culture natural resources will be economic growth when recources it can be in governance well consistent with what most attractive to the community so the utilization of natural resources it will not spend time or matter due to the failure to shift in managing a resources. As is the case in a waterfall Kebo Amuk in the villagers Sitilubur in Gembong Pati. Research aims to understand the role in the development of a waterfall kebo amuk in the development of economic the village community sitilubur, conducted by looking at, how the role and strategy in development tourist destinations a waterfall kebo amuk (Tedunan of community economy improvement, whatever the factors that appear in the development of tourism a waterfall kebo amuk (Tedunan), how impacts viewed from development tourist destinations a waterfall kebo amuk (Tedunan). The research is a fieldwork adopting descriptive. A method of data collection was carried out by interviews, observation, and documentation . Analysis done with analysis qualitative milles and buberman through a process data collection, data reduction, data display, verification data. In which the validity of the data using a technique trianggulasi good interview, observation, and documentation. As for the findings in thesis this is a village that has the potential natural have not yet been widely exumated and development as in waterfall Kebo Amuk (Tedunan). The process of development a waterfall Kebo Amuk be conducted by way of planning, the implementation, of the evaluation. As for the goal is to improve on the community economy. A method which is executed is to optimize the use of these roles with from stakeholders. The evaluation is done as a
\end{abstract}


FAIZ AMINUDDIN dan ABDUL MUTHOLIB

whole ranging from cognitive aspect of, effective, psychomotor. Stage of the proceeding the development of a waterfall Kebo Amuk done with planning, the implementation of the, evaluation.

Keywords: Waterfall Kebo Amuk, Development.

\section{A. Pendahuluan}

Negara Indonesia merupakan negara yang memiliki potensi sumber daya yang berlimpah, keanekaragaman hayati dan peninggalan sejarah dan budaya. Berlimpahnya sumberdaya alam yang ada dapat mengingkatkan pertumbuhan ekonomi ketika sumber daya tersebut dapat di kelola dengan baik sesuai dengan apa yang paling diminati masyarakat sehingga pemanfaatan sumberdaya alam tersebut tidak akan menghabiskan waktu ataupun materi akibat ketidakberhasilan dalam mengelola suatu sumber daya.

Pariwisata merupakan salah satu pemanfaatan sumber daya yang dapat bernilai ekonomi tinggi bagi suatu daerah yang mengelola sumber daya alam menjadi suatu tempat wisata yang dapat menarik pengunjung baik dari manapun dari luar negri, disamping bernilai ekonomi yang tinggi, pariwisata dapat menumbuhkan dan meningkatkan rasa bangga terhadap bangsa sehingga akan tumbuh masyarakat yang lebih peduli terhadap suatu bangsa. Pariwisata adalah hal yang diminati oleh setiap individu, karena dapat menghilangkan kejenuhan, dan juga di dorong oleh keinginan untuk mengenal, atau mempelajari suatu daerah dan kebudayaan lokal. ${ }^{1}$

Sektor pariwisata sebagai kegiatan perekonomian telah menjadi andalan dan prioritas pengembangan bagi sejumlah negara, terlebih bagi Negara berkembang seperti Indonesia yang memiliki potensi wilayah yang luas dengan adanya daya tarik wisata cukup besar, banyaknya keindahan alam, aneka warisan sejarah budaya dan kehidupan masyarakat. dan objek wisata yang ada di Kabupaten Pati Provinsi Jawa Tengah, merupakan salah satu dari kekayaan alam yang patut untuk dibanggakan. Setiap daerah di Indonesia memiliki keunikan baik dari segi keindahannya maupun adat istiadat yang ada di daerah tersebut sehingga menarik minat wisatawan untuk mengunjunginya.

\footnotetext{
${ }^{1}$ I Gede Patana, Sosiologi Pariwisata (Yogyakarta: Andi,2005), hlm. 81.
} 
Banyak dari objek wisata yang ada saat ini pada awalnya bukan suatu tempat objek wisata, tetapi setelah mengetahui bahwa tempat tersebut memiliki potensi yang baik, maka kemudian tempat tersebut berkembang menjadi objek wisata. Seperti Taman Nasional Gunung Ciremai yang beralih fungsi dari kawasan hutan lindung menjadi Taman Nasioanal Gunung Ciremai dan khususnya Air Terjun Kebo Amok yang aslinya adalah aliran sungai dari pegunungan Muria. ${ }^{2}$ Saat ini pengelolaan pada objek wisata di Air Terjun Kebo Amuk (Tedunan) belum terkelola dengan baik, seperti managemen pengelolaan masih belum professional, kurangnya aktivitas wisata, sarana dan prasarana masih kurang memadai, proses pemberian informasi belum terorganisir atau tersampaikan dengan baik.

Dengan melihat keadaan tersebut diperlukan suatu peranan managemen untuk penyampaian informasi yang baik akan objek wisata Air Terjun Kebo Amuk (Tedunan) agar masyarakat luar mengenal dan dapat menikmati fasilitas yang disediakan di objek wisata Air Terjun Kebo Amuk (Tedunan) tersebut. Bentuk upaya yang dapat dilakukan antara lain dengan melakukan promosi yang lebih terencana dan teratur supaya promosi tersebut dapat mencapai hasil sesuai yang diinginkan, yaitu informasi tersampaikan dengan baik dan mudah sekaligus meningkatkan minat masyarakat luar maupun local untuk lebih mengenal objek wisata baik dengan cara langsung ataupun tidak. Serta memperbaiki dan menambahi sarana dan prasarana guna kenyamanan para wisatawan. Karena hal tersesebut akan berdampak pada peningkatan ekonomi masyarakat sekitar objek wisata.

\section{B. Gambaran Umum Desa Sitiluhur}

Desa Sitiluhur terletak Di Kecamatan Gembong Kabupaten Pati. Propinsi Jawa Tengah, Jarak ke Ibu Kota Kecamatan diperkirakan 9 KM sedangkan Jarak ke Ibu Kota Kabupaten kurang lebih $15 \mathrm{KM}$.

1. Potensi

Potensi yang ada Desa Sitiluhur sangatlah beragam potensi. Karena wilayah Desa Sitiluhur lumayan luas. Potensi-potensi tersebut antara lain:

a. Potensi Sumber Daya Manusia (SDM)

\footnotetext{
${ }^{2}$ Wawancara dengan Bapak Suyuti tanggal 23 September 2016.
} 
Sumber daya manusia merupakan pilar utama sekaligus penggerak roda organisasi dalam upaya mewujudkan visi dan misinya. Karenanya harus dipastikan sumber daya ini dikelola dengan sebaik mungkin agar mampu member kontribusi secara optimal. Maka diperlukanlah sebuah pengelolaan secara sistematis dan terencana agar tujuan yang diinginkan dimasa sekarang dan masa depan bisa tercapai yang sering disebut sebagai manajemen sumber daya manusia. ${ }^{3}$ Adapun SDM yang dimiliki Desa Sitiluhur antara lain laki-laki: 1.968 orang, perempuan: 1942 orang, Total: 3.910 orang, jadi untuk mengembangkan Desa Sitiluhur sebenarnya sudah cukup memadahi, namun semua itu perlu adanya penggerak dan pencetus agar SDM tersebut bisa bermanfaan bagi Desa Sitiluuhur. ${ }^{4}$

b. Sumber Daya Alam

Potensi sumber daya alam yang ada di wilayah sekitar Desa Sitiluhur meliputi beberapa macam potensi Alam yakni di antaranya, Air Terjun Kebo Amuk (Tedunan), Air Terjun Argo Jolong, Kebun Kopi Jolong, Waduk Gunung Rowo, Air Terjun Grenjengan Lor, dan Air Terjun Grenjengan Kulon. Khusus dua Air Terjun dua yang terakhir itu, belum dikelola pemerintah atau investor. Padahal keduanya sama-sama memiliki curah air yang lumayan besar dan sejuk. Dari hasil observasi data bahwa potensi yang lebih dominan ada di sekitar objek Wisata Air Terjun Kebo Amuk (Tedunan), Wisata Kebon Kopi Jolong, dan Waduk Gunung Rowo, yang paling besar memberikan penghasilan kepada masyarakat di sekitar wisata. ${ }^{5}$ Namun pada pertetnakan ikan dan perkebunan itu semua hanyalah musiman. Akan tetapi dari segi potensi perikanan dan perkebunan ini bisa membawa tambahan penghasilan bagi masyarakat sekitar. Maka dari itu dari segi sumber daya perikanan memberikan nilai lebih kepada masyarakat setempat khususnya adalah para pedagang untuk memenuhi kebutuhan hidup sehari-harinya.

c. Ekonomi

\footnotetext{
${ }^{3}$ Observasi tanggal 25 Desember 2016.

${ }^{4}$ Sumber: Data kantor pemerintah Desa Sitiluhur.

${ }^{5}$ Wawancara dengan Bapak Suyuti tanggal 25 Desember 2016.
} 
Desa Sitiluhur terkait masalah ekonomi memang tergolong Desa yang masih kurang sejahtera atau masih mayoritas yang mengalami kemiskinan. Ini bisa dilihat dari sedikitnya lapangan kerja yang ada, dan banyaknya para penduduk yang mencari nafkah di negeri seberang atau sebagai perantau dan pedangang. Sebetulnya Desa Sitiluhur mempunyai banyak potensi-potensi yang bisa ditumbuh kembangkan atau dimanfaatkan untuk mendapatkan pemasukan setidaknya bisa menambah pendapatan ekonomi sehari-hari. Namun karena banyaknya faktor-faktor negative akhirnya potensi-potensi tersebut hanya bisa dimanfaatkan sebagian saja. ${ }^{6}$

Di antara objek wisata yang ada di Desa Sitiluhur adalah sarana atau lahan yang prospektif kedepannya karena dari Objek Wisata bisa dijadikan batu loncatan dalam pengembangan ekonomi masyarakat desa sekitar Objek Wisata Air Terjun Kebo Amuk (Tedunan) Menurut mas Zaenal Arifin yang selaku Ketua Paguyuban Objek Wisata Air Terjun (Tedunan) wisata tersebut sudah ada perkembangan atau wisatawan dari bulan kebulan menjadi semankin meningkat. ${ }^{7}$

\section{Peran dan Strategi Dalam Pengembangan Objek Wisata Air Terjun Kebo Amuk (Tedunan) Terhadap Peningkatan Ekonomi Masyarakat}

Peran dalam pengembangan objek wisata Air Terjun Kebo Amuk (Tedunan) Desa Sitiluhur Kecamatan Gembong Kabupaten Pati yang dimaksud disini adalah peran seorang stakeholder dalam melakukan tanggungjawabnya sebagai tokoh masyarakat (perangkat desa Sitiluhur) dalam melayani masyarakatnya serta dalam mengembangkan potensi lokal yang dimiliki oleh desa tersebut (objek wisata Air Terjun Kebo Amuk). Maka untuk bisa terealisasi dengan baik, peran dari stakeholder disini sangat dibutuhkan oleh masyarakat Sitiluhur kaitantanya dalam pengembangan objek wisata Air Terjun Kebo Amuk (Tedunan) Desa Sitiluhur Kecamatan Gembong Kabupaten Pati. Oleh karena itu, menurut bapak Suyuti8 kepala desa Sitiluhur menjelaskan bahwa:

\footnotetext{
${ }^{6}$ Observasi tanggal 25 Desember 2016.

${ }^{7}$ Wawancara bapak A Salim tanggal 3 Januari 2017.

${ }^{8}$ Wawancara Bapak Suyuti Selaku Kepala Desa Sitiluhur Hari Selasa 12 Desember 2016.
} 
FAIZ AMINUDDIN dan ABDUL MUTHOLIB

'Peran yang diambil dalam pengembangan wisata Air Terjun Kebo Amuk (Tedunan) adalab dengan menempatkan beberapa staf perangkat Desa untuk pro-aktif, kaitannya dalam pengembangan wisata Air Terjun Kebo Amuk, biasanya dengan cara memberikan pengarahan dan contoh terhadap masyarakatnya, mendorong masyarakat untuk kreatif dan aktif dalam berpartisipasi, memberikan pelatiban administrasi terhadap pengurus agar tertib dalam melakukan laporan dan melatih disiplin dalam melakukan segala pekerjaan, menjalin kerjasama dan relasi terhadap pihak-pibak terkait untuk memajukan wisata air terjun Kebo Amuk agar bisa berdaya saing menuju masyarakat yang sejabtera."

Penjelasan di atas dapat ditarik bahwa peran yang diambil dengan menempatkan beberapa staf perangkat Desa Sitiluhur untuk proaktif, kaitanya untuk memberikan pengarahan dan mendorong masyarakat untuk kreatif dan aktif dalam melakukan partisipasi dan menjalin kerjasama terhadap pihak-pihak terkait. Dan menertikan dalam melakukan laporan dan disiplin untuk memberikan pelatiahan dalam segala pekerjaan terkait untuk memajukan objek wisata Air Terjun KeboAmuk (Tedunan) dan meningkatkan ekonomi masyarakat disekitar wisata.

Peran dari perangkat desa diatas sesuai dengan visi dari objek wisata Air Terjun Kebo Amuk di desa Sitiluhur yakni Terwujudnya Air Terjun Kebo Amuk (Tedunan) desa Sitiluhur kecamatan Gembong kabupaten Pati sebagai tujuan pariwisata yang berdaya saing menuju masyarakat yang sejahtera. ${ }^{9}$ Selain itu menurut Ahmad Salim selaku ketua pengurus objek wisata Air Terjun Kebo Amuk menjelaskan bahwa:

"Saya mengajak masyarakat Sitilubur agar sadar akan potensi yang dimiliki oleh desa kita ini, oleh karena itu pendidikan tentang kesadaran dan kesadaran dalam berfikir kritis serta untuke kreatif dalam memajukan air terjun ini, mari kita bersama-sama untuk membangun dan memperbaiki air terjun ini dengan belajar dan menjalin kerjasama dengan stakeholder yang ada. Agar air terjun ini kedepan bisa mendatangkan banyak pengunjung dan bisa mendapatkan pendapatan ekonomi terhadap masyarakat.",10

${ }^{9}$ Disajikan Dalam Visi Air Terjun Kebo Amuk Desa Sitiluhur Kecamatan Gembong Kabupaten Pati.

${ }^{10}$ Wawancara Ahmad Salim ketua pengurus Air Terjun Kebo Amuk tangal 5jjanuari 2017. 
Dari pemaparan di atas dapat diketahui bahwa masyarakat agar sadar akan potensi yang dimiliki oleh Desa Sitiluhur dan membangun dan memperbaiki wisata Air Terjun dan masyarakat kedepan bisa menarik sebanyak-banyaknya pengunjung dan meningkatkan pendapatan ekonomi masyarakat.

Peran yang diterapkan oleh Bapak Ahmad Salim sesuai dengan peran pendidikan yang dikutip dari bukunya Aziz Muslim ${ }^{11}$ dimana peran tersebut adalah dalam bentuk pendidikan yaitu:

"Peran-peran kependidikan. Dalam pengembangan masyarakat terjadi proses pembelajaran terus menerus dari masyarakat maupun pekerja kemasyarakatan untuk selalu memperbaiki ketrampilan, cara berfikir, cara berinteraksi, cara mengatasi masalah dan lain sebagainya. Peran ini meliputi consciousness raising (membangun kesadaran), confronting (mempertentangkan sebagai taktik dinamisasi kelompok) dan training (pelatihan)."

Selain itu peran di atas juga sesuai dengan apa yang dijelaskan oleh Soerjono Soekamto. Menurut Soerjono Soekamto peran ada tiga yaitu: pertama, Peran meliputi norma-norma yang dihubungkan dengan posisi atau tempat seseorang di dalam masyarakat. Peran dalam arti ini merupakan rangkaian peraturan-peraturan yang membimbing seseorang dalam kehidupan kemasyarakatan. Dalam hal ini hubungan-hubungan sosial yang ada dalam masyarakat merupakan hubungan antara peranan-peranan individu dalam masyarakat dimana peran tersebut diatur oleh norma-norma dalam masyarakat. Kedua, Peran adalah suatu konsep perihal apa yang dapat dilakukan oleh individu dalam masyarakat sebagai organisasi. Dimana setiap orang dalam suatu organisasi di masyarakat menjalankan sebuah peranan sesuai dengan kedudukan yang dimilikinya. Ketiga, Peran juga dapat dikatakan sebagai perikelakuan individu yang penting bagi struktur sosial masyarakat. pentingnya peran adalah untuk mengatur perilaku seseorang dan juga menyebabkan seseorang pada batas-batas tertentu dapat meramalkan perbuatan-perbuatan orang lain.

Menurut analisis peneliti saat melakukan observasi di lapangan, bahwa Desa Sitiluhur memiliki potensi yang sangat luar biasa, seperti Air Terjun Kebo Amuk, Waduk Gunung Rowo, dan Wisata Agro Jolong akan tetapi khusus yang Air Terjun Kebo Amuk kurang

${ }^{11}$ Aziz Muslim, Dasar-Dasar Pengembangan Masyarakat, (Yogyakarta: Samudra Biru, 2009), hlm. 26. 
FAIZ AMINUDDIN dan ABDUL MUTHOLIB

begitu terekspos oleh media. Sehingga keberadaannya belum banyak dikenal oleh masyarakat secara luas. Maka, dengan adanya keperhatian dari Pemerintah Desa dan adanya mahasiswa Institut Mathali'ul Falah saat melakukan Kuliah Kerja

Nyata (KKN). Keberadaan Air Terjun Kebo Amuk mulai terpublikasikan dan mulai ramai kedatangan pengunjung yang berlibur di Air Terjun Kebo Amuk sehingga peran dari stakeholder Desa Sitiluhur sangat dibutuhkan oleh masyarakat agar eksistensi keberadaan Air Terjun Kebo Amuk ini biar tetap eksis dan lebih banyak lagi pengunjung yang berwisata di Air Terjun Kebo Amuk. Sehingga bisa berdampak dalam peningkatan income ekonomi masyarakat. $^{12}$

\section{Faktor-Faktor Yang Muncul Dalam Pengembangan Objek Wisata Air Terjun}

\section{Kebo Amuk}

Pengembangan berasal dari kata kembang yang artinya menjadi maju, sempurna, berkembang. Kemudian mendapat imbuhan peng-an, sehingga menjadi kata pengembangan. ${ }^{13}$ dari, kata pengembangan adalah proses, cara, perbuatan mengembangkan sesuatu hal agar dapat bertambah maju berkembang dan menuju ke arah kesempurnaan. Secara etimologis pengembangan berarti membina dan meningkatkan kualitas. ${ }^{14}$

Pada hakikatnya pengembangan adalah upaya pendidikan baik formal maupun non formal yang dilaksanakan secara sadar, berencana, terarah, teratur dan bertanggung jawab dalam rangka memperkenalkan, menumbuhkan, membimbing, mengembangkan suatu dasar kepribadian yang seimbang, utuh, selaras, pengetahuan, keterampilan sesuai dengan bakat, keinginan serta kemampuan-kemampuan, sebagai bekal atas prakarsa sendiri untuk

${ }^{12}$ Observasi 22 Desember 2016.

${ }^{13}$ Peter Salim dan Yenny Salim, Kamus Bahasa Indonesia Kontemporer, Jakarta: Modern English Press, 1991), hlm. 700 .

${ }^{14}$ Nanih Mahendrawaty dan Agus Ahmad Syafi'I, Pengembangan Masyarakat Islam dan Ideologi Strategi, (Bandung: Rosdakarya, 2001), hlm. 29. 
menambah, meningkatkan, mengembangkan diri ke arah tercapainya martabat, mutu dan kemampuan manusiawi yang optimal serta pribadi mandiri. ${ }^{15}$

Hal ini sesuai dengan penjelasan Ahmad Salim selaku ketua pengurus objek wisata Air Terjun Kebo Amuk, kaitannya dalam pengembangan air terjun Kebo Amuk adalah sebagai berikut:

"Dalam melakukan pengembangan terkait dengan air terjun Kebo Amuk perlu diperbatikan adalah perbaikan akses masuk, perbaikan inafraktruktur jalan dan bangunan fisik. Karena selama ini yang menjadi kendala adalah akses jalan masuk menuju lokasi yang masib buruk dan sempitnya jalan ke lokasi. Sebingga sangat perlu sekali untuk dilakukan perbaikan.",16

Dalam penjelasan diatas dapat ditarik kesimpulan bahwa pengembangan merupakan suatu usaha yang dilakukan secara sadar, terencana, terarah untuk membuat atau memperbaiki, sehingga menjadi tempat wisata yang semakin bermanfaat untuk meningkatkan kualitas sebagai upaya untuk menciptakan mutu yang lebih baik. ${ }^{17}$ Adapun faktor-faktor yang muncul kaitannya dalam pengembangan objek wisata Air Terjun Kebo Amuk saat melakukan observasi di antaranya adalah sebagai berikut:

1) Kurangnya pendanaan dalam hal sarana prasarana untuk akses jalan masuk ke objek wisata Air Terjun Kebo Amuk.

Faktor pendanaan dalam sarana dan prasarana saat peneliti terjun langsung ke lokasi memang masih dalam tahap proses perbaikan dan jauh sebelum mulai dikenal masyarakat secara luas keberadaan objek wisata Air Terjun Kebo Amuk ini memang belum memiliki sarana prasarana yang baik. Bahkan akses untuk masuk saja masih kesulitan dalam untuk bisa kelokasi. Sehingga sarana prasarana sangat penting sekali untuk memajukan dan mempromosikan objek wisata Air Terjun Kebo Amuk. Maka sarana dan prasarana ini sangat penting. ${ }^{18}$ Faktor di atas sudah diakui oleh Ahmad Salim selaku ketua pengurus Air Terjun Kebo Amuk, dia mengatakan bahwa:

\footnotetext{
${ }^{15}$ Tessmer dan Richey, Pengembangan Masyarakat dan Strategi Analisis, (Pustaka Pelajar, 2001), hlm. 35.

${ }^{16}$ Wawancara dengan Bapak Ahmad Salim tanggal 27 Desember 2017.

${ }^{17}$ Pdf. Pengertian Pengembangan, hlm. 8

${ }^{18}$ Observasi 2 Januari 2017.
} 
"Dengan keterbatasan dana serta tenaga ahli dalam tatakelola air terjun tersbut. Maka dari kami sebisanya melakukannya, yang jelas sudah ada usaha atau ikhtiar, agar air terjun ini tetap bisa eksis akan keberadaannya dan tetap banyak pengunjungnya". ${ }^{19}$

2. Kurangnya relasi baik dari tingkat pemerintah daerah maupun dari pihak stakeholder lainnya.

Faktor kurang terjalinnya relasi dari pemerintah maupun dari pihak-pihak terkait memang masih menjadi problem. Sehingga faktor ini berdampak dalam objek wisata Air Terjun Kebo Amuk. Di mana untuk memajukan dan mempromosikan butuh yang namanya dana. Adapun untuk mendapatkan dana yang besar butuh yang namanya relasi dari beberama elemen masyarakat baik itu dari pemerintah daerah, stakeholder maupun dari pihak-pihak terkait. Sehingga dengan adanya relasi diharapkan adanya sumbangsih untuk perbaikan objek wisata Air Terjun Kebo Amuk. Hal senada juga disampaikan oleh Suyuti bahwa: ${ }^{20}$

"kurangnya relasi dalam menjalin kerjasama baik dari pemerintah daerah maupun dari stakeholder memang kurang disini mas, karena selama ini belum terfikirkan untuk memajukan objek wisata Air Terjun Kebo Amuk ini. lambat laut dengan berjalannya waktu dan semakin banyaknya hampir setiap harinya rata-rata ada 50-80 pengunjung ke objek wisata, sudah mulai saya pikirkan untuk menjalin kerjasama dengan pibak-pibak terkait."

3) Kurangnya publikasi media, baik cetak maupun online.

Kurangnya akses publikasi memang sangat minim sekali bahkan jarang sekali. Sehingga faktor publikasi dalam mempromosikan objek wisata Air Terjun Kebo Amuk tergolong sangat minim. Sehingga masyarakat untuk mengetahui tergolong sangat sedikit. Oleh karena itu menurut peneliti, publikasi sangat penting untuk mempromosikan objek wisata tersebut. Faktor publikasi juga dirsakan oleh bapak Suyuti kaitannya untuk mengenalkan objek wisata ini. maka untuk mencari solusinya pertama, membuat web desa Sitiluhur agar fungsi web ini bisa memberikan akses kemudahan informasi terkait potensi

\footnotetext{
${ }^{19}$ Wawancara Ahmad Salim.

${ }^{20}$ Wawancara dengan Bapak Suyuti tangal 5 Januari 2017.
} 
lokal objek wisata yang ada di Kabupaten Pati khususnya di Desa Sitiluhur Kecamatan Gembong Kabupaten Pati. Kedua, menggandeng kerjasama dengan media cetak maupun onlin untuk mempublikasi objek wisata air terjun Kebo Amuk ini. Terakhir, ketiga, mengajak masyarakat Sitiluhur untuk melek aksara, melek huruf dan untuk tidak iptek dalam menggunakan media sosial. Karena dengan aktif dimedia sosial, semua yang kita ketik dan kita aploud akan dilihat oleh semua orang tentunya dalam hal yang bersifat positif untuk memajukan desa Siti luhur. ${ }^{21}$

Dalam penjelasan di atas dapat diketahui bahwa masyarakat dan pemerintah desa sangat minim di bidang masalah pendanaan serta tenaga para ahli dalam melakukan menginovasi terhadap lokasi wisata Air Terjun, masyarakat berharap pemerintah desa dan pengelola wisata dapat menjadikan wisata Air Terjun ini tetap eksis dan mampu berdaya saing dengan wisata-wisata yang lainnya.

\section{E. Dampak Dari Pengembangan Objek Wisata Air Terjun Keo Amuk}

Dampak yang dirasakan dengan adanya Air Terjun Kebo Amuk (Tedunan) sangat terasa sekali yang dirasakan oleh beberapa masyarakat Desa Sitiluhur. Sehingga dampak ini memberikan respon positif dari stakeholder setempat maupun dari pemerintah daerah. Adapun beberapa dampak yang dirasakan oleh masyarakat Desa Sitiluhur adalah sebagai berikut:

a) Adanya pengunjung yang berbondong-bondong datang ke lokasi objek wisata Air Terjun Kebo Amuk.Hal ini bisa dilihat dari jauh sebelum objek wisata ini popular, karena sebelumnya sedikit sekali yang datang di lokasi. Akan tetapi silih berganti waktu pengunjuk mulai melonjak rata-rata menurut penuturan bapak Suyadi warga setempat 50-80 perharinya. Bahkan kalau hari-hari tertentu seperti hari minggu maupun hari libur lainnya sampai mencapai ratusan, jumlah pengunjung yang memadati objek wisata Air Terjun Kebo Amuk. Hal ini juga dirasakan oleh Aris salah satu juru parkir bahwa: ${ }^{22}$

"Rata-rata pengunjung yang datang kesini adalah remaja mas, biasanya kalau hari bisah seperti hari senin sampai hari kami pengunjung ya tidak banyak tapi ya adalah tapi kalau hari libur

\footnotetext{
${ }^{21}$ Wawancara Suyuti 2 Januari 2017.

${ }^{22}$ Wawancara dengan Aris, Juru Parkir Wisata Air Terjun tanggal 25 Desember 2016.
} 
FAIZ AMINUDDIN dan ABDUL MUTHOLIB

biasanya jumlah berkali lipat mas, kalau hari minggu atau libur mencapai ratusan, adapun kalau hari-hari biasa 50-70 perharinya."

Dari pemaparan di atas dapat diketahui bahwa rata-rata pengenunjung wisata seperti hari senin sampai kamis pengunjung wisata agak sedikit, tapi kalau hari libur jumblah pengunjung pasti banyak hingga mencapai ratusan pengunjung.

b) Adanya lonjakan pendapatan ekonomi masyarakat.

Adanya lonjakan pendapatan ekonomi dirasakan oleh masyarakat desa Sitiluhur. Salah satunya menurut penuturan ibu Sukini menjelaskan bahwa:

"Dengan adanya objek wisata ini Alhamdulillah pendapatan kulo perhari bisa mencapai 150-

200 ribu mas, bahkan bisa lebih. Kalau biasanya hanya mencapai 50-75 ribu akan tetapi dengan adanya objek wisata ini bisaa menambah ekonomi saya mas. ${ }^{23}$

Penjelasan di atas dapat diketahui bahwa dengan adanya objek wisata Air Terjun tersebut dapat meningkatkan perekonomian masyarakat yang berada di sekitar wisata objek wisata Air Terjun serta dapat memberikan lapangan pekerjaan kepada masyarakat baik ibuibu maupun pemuda yang ada di sekitar wisata.

c) Adanya perbaikan akses sarana-prasarana untuk menuju ke objek wisata Air Terjun Kebo Amuk. Dengan adanya perbaikan akses sarana dan prasarana, maka akan semakin mudah akses masuk kelokasi. Sehingga pengunjung akan merasa nyaman dan mudah dalam menuju ke lokasi. Oleh karena itu faktor sarana dan prasarana sangat penting untuk memberikan kemudahan dan kenyamanan bagi pengunjung yang ingin berwisata di Air Terjun Kebo Amuk.

d) Semakin terkenalnya objek wisata Air Terjun Kebo Amuk dengan adanya publikasi media. Faktor publikasi tidak bisa dipungkiri lagi, karena dengan melek media dan selalu aktif serta menggandeng kerjasama dengan media baik cetak maupun online, hal apapun kalau sudah dimuat dalam media cetak maupun online dampaknya langsung akan di respon atau dibaca oleh banyak orang dalam waktu sekejap faktor media sangat penting untuk mempromosikan bentuk apapun, kalau disini adalah kaitannya Air Terjun Kebo Amuk.

\footnotetext{
${ }^{23}$ Wawancara dengan Ibu Sukini, Pedagang Wisata Air Terjun, tanggal 25 Desember 2016
} 
Apalagi setelah adanya kunjungan dari Bupati Hariyanto waktu itu, banyak media yang mengekspos keberadaan objek wisata ini, karena ada figur orang nomor satu di Pati. Maka tidak heran mengundang banyak orang yang penasaran datang kelolasi tersebut. Seperti dalam penuturan saudara Muhammad Faqih salah satu pengunjung menjelaskan bahwa:

"Saya datang ke sini karena penasaran seperti apa keindahan objek wisata Air Terjun ini mas, saya melihat di medsos banyak pengunjung yang datang dilokasi tersebut. Dan selain itu untuk. refresing mas, jadi kalau mau liburan dengan keluarga tidake perlu jauh-jauh cukup di daerah sendiri saja sudah banyak wisata sekarang., ${ }^{24}$

Jadi penuturan diatas dapat disimpulkan bahwa pengunjung datang karena rasa penasaran terhadap wisata Air Terjun Kebo Amuk (Tedunan), wisata ini juga dapat dibuat tempat liburan buat keluarga untuk mengisi waktu liburan dan lokasinya juga masih di daerah sendiri.

e) Adanya bantuan dari pemerintah daerah yang peduli akan keberadaan objek wisata Air Terjun Kebo Amuk. Sehingga keberadaanya semakin dikenal oleh masyarakat secara luas. Faktor bantuan dari pemerintah setempat juga sangat mempengaruhi dalam hal memajukan objek wisata ini, tentunya dalam bentuk sumbangsih pendanaan baik itu berupa bantun meteriil maupun nonmeteriil. ${ }^{25}$

Selain itu dampak yang bisa dilihat dari pengembangan objek wisata Air Terjun Kebo Amuk (Tedunan) adalah:

1) Menjaga dan merawat kelestarian alam yang ada di Desa Sitiluhur yaitu Wisata Air Terjun Kebo Amuk (Tedunan), dan

2) mengembangkan wisata tersebut sehingga dapat meningkatkan perekonomian masyarakat yang berada di sekitar wisata Air Terjun.

3) Terciptanya lapangan pekerjaan untuk masyarakat Desa Sitiluhur, yang dahulunya pemuda lebih senang merantau karena di desanya tidak mempunyai pekerjaan, tapi dengan adanya Objek Wisata Air Terjun Kebo Amuk ini dapat menambah atau menciptakan lapangan pekerjaan terhadap masyarakat Desa Sitiluhur.

\footnotetext{
${ }^{24}$ Wawancara dengan Muhamad Faqih, Pengunjung Wisata, tanggal 17 Januari 2017.

25 Observasi 2 Januari 2017
} 
4) Adanya peningkatan income ekonomi masyarakat dengan adanya wisata Air Terjun Kebo Amuk tersebut, yaitu dengan banyaknya pengunjung yang berbondongbondong mendatangi objek wisata Air Terjun Kebo Amuk, baik dari daerah Pati maupun dari luar daerah Pati.

5) Terciptanya ekonomi kreaktif masyarakat, seperti membuat kaos, makanan, dan asesoris, yang menunjukan ciri khas wisata Air Terjun Kebo Amuk (Tedunan), agar semakin terkenalnya wisata ini di kalangan masyarakat Pati.

Melihat dampak yang terlihat dalam objek wisata Air Terjun Kebo Amuk ini menurut Bapak Kepala Desa Sitiluhur mempunyai harapan yang sangat tinggi, kedepan objek wisata Air Terjun Kebo Amuk ini akan semakin tinggi animo pengunjung yang mendatangi objek wisata ini. Hal senada juga diungkapkan oleh Sekretaris desa Sitiluhur bahwa ${ }^{26}$

"Melihat dampak yang dirasakan oleh masyarakat desa Sitilubur dengan adanya bantuan dan kerjasama dari pemerintah daerah maupun dari pibak-pibak terkait. Sangat tidak mungkin kedepan objek wisata Air Terjun Kebo Amuk ini akan semakin diminati oleh pengunjung tidak hanya dari Pati akan tetapi juga dari luar Pati."

Maka, dapat dilihat bahwa dampak dari adanya wisata Air Terjun tersebut setelah bekerjasama dengan pemerintah daerah dan pihak-pihak terkait, maka kedepanya objek wisata Air Terjun KeboAmuk (Tedunan) pasti akan semakin ramai oleh pengunjung wisatawan, dan pasti akan meningkatkan perekonomian masyarakat yang berada disekitar wisata Air Terjun.

Dengan demikian dari adanya peran baik dari stakeholder tokoh masyarakat setempat maupun dari pihak-pihak terkait. Objek wisata Air Terjun Kebo Amuk (Tedunan) mulai banyak diminati oleh banyak pengunjung. Tidak hanya itu dengan adanya media sosial air terjun ini sudah terdengar dari berbagai kalangan. Selain itu, objek wisata ini bisa lebih bervariasi apabila kalau ada inovasi maupun perbaikan dari berbagai hal mulai dari wahana wisata yang mendukung di sekitar Air Terjun Kebo Amuk (Tedunan). Sehingga dengan

\footnotetext{
${ }^{26}$ Observasi tanggal 25 Desember 2016
} 
adanya beberapa wahana yang ditambah di sekitar objek wisata tersebut, bukan tidak mungkin akan semakin banyak pengunjung yang memadati air terjun tersebut.

\section{F. Kesimpulan}

Peran dan strategi pengembangan objek pariwisata Air Terjun Kebo Amuk (Tedunan) Desa Sitiluhur Kecamatan Gembong Kabupaten Pati dilakukan dengan cara melakukan meningkatkan kesejahteraan masyarakat dan untuk melakukan pengembangan objek pariwisata. Adapun tujuannya adalah untuk pengembangan ekonomi masyarakat desa Sitiluhur Kecamatan Gembong Kabupaten Pati. Metode yang digunakan adalah dengan menggunakan teori peran. Peran disini untuk mengambil keputusan dan kebijakan dalam melakukan pengembangan objek pariwisata air terjun Kebo Amuk (Tedunan) Desa Sitiluhur Kecamatan Gembong Kabupaten Pati.

Faktor-faktor yang muncul dalam pengembangan objek pariwisata Air Terjun Kebo Amuk (Tedunan) Desa Sitiluhur Kecamatan Gembong Kabupaten Pati. Pertama, kurangnya pendanaan dalam hal sarana dan prasarana untuk mengembangkan objek wisata Air Terjun Kebo Amuk. Kedua, kurangnya relasi baik dari tingkat pemerintah daerah maupun dari pihak stakeholder lainnya. Ketiga, kurangnya ekspos media baik cetak maupun onlin.

Dampak yang dapat dilihat dari pengembangan Air Terjun Kebo Amuk (Tedunan) Desa Sitiluhur Kecamatan Gembong Kabupaten Pati. Beberapa dampak yang bisa dilihat dalam pengembangan objek pariwisata pengembangan Air Terjun Kebo Amuk adalah; pertama, Adanya pengunjung yang berbondong-bondong datang kelokasi objek wisata Air Terjun Kebo Amuk. kedua, adanya perbaikan akses sarana-prasarana untuk menuju ke objek wisata Air Terjun Kebo Amuk. Ketiga, semakin terkenalnya objek wisata Air Terjun Kebo Amuk dengan adanya publikasi media. Keempat, Adanya bantuan dari pemerintah daerah yang peduli akan keberadaan objek wisata Air Terjun Kebo Amuk. Sehingga keberadaanya semakin dikenal oleh masyarakat secara luas. 


\section{Daftar Pustaka}

Patana, I Gde, 2005, Sosiologi Pariwisata, Yogyakarta: Andi

Yelly, Desri, Faktor-Faktor Yang Mempengaruhi Kunjungan Wisatawan Pada Kawasan Objek Wisata Air Terjun Tujuh Tingkat Di Kecamatan Hulu Kuantan Kabupaten Kuantan Singingi Riau

Sumber: Data kantor pemerintah Desa Sitiluhur

Muslim, Aziz, 2009, Dasar-Dasar Pengembangan Masyarakat, Yogyakarta: Samudra Biru

Salim, Peter dan Yenny Salim, 1991, Kamus Bahasa Indonesia Kontemporer, Jakarta: Modern English Press

Mahendrawaty, Nanih dan Agus Ahmad Syafi'I, 2001, Pengembangan Masyarakat Islam dan Ideologi Strategi, Bandung: Rosdakarya

Tessmer dan Richey, 2001, Pengembangan Masyarakat dan Strategi Analisis, Pustaka Pelajar

Observasi 2 Januari 2017

Wawancara dengan Bapak Suyuti tangal 5 Januari 2017

Wawancara Suyuti 2 Januari 2017

Observasi tanggal 25 Desember 2016 